\title{
A Comprehensive Framework for the Analysis of Industry 4.0 Value Domains
}

\author{
César Martínez-Olvera ${ }^{1, *}$ and Jaime Mora-Vargas ${ }^{2}$ (D) \\ 1 School of Business and Economy, Universidad de las Américas Puebla (UDLAP), \\ San Andrés Cholula 72810, Mexico \\ 2 School of Engineering and Sciences, Tecnológico de Monterrey (ITESM), Campus Estado de México, \\ Atizapán de Zaragoza, Ciudad López Mateos 52290, Mexico; jmora@itesm.mx \\ * Correspondence: cesar.martinezo@udlap.mx
}

Received: 11 April 2019; Accepted: 6 May 2019; Published: 24 May 2019

\begin{abstract}
Industry 4.0 aims to ensure the future competitiveness of the manufacturing industry by providing Companies with the ability to react to rapid product changes and disturbances, efficiently and reliably, through re-configurability. In this paper, we explore the value creation process within Industry 4.0, with special emphasis on its relationship with mass customization and the sustainability issue. Based on the identified research gaps and opportunities derived from a literature review of relevant concepts, we propose the development of the Customer-Product-Process-Resource (CPPR) 4.0, a comprehensive framework that puts the value proposition-creation-capture cycle proper of an Industry 4.0 environment, in the context of a manufacturing organization's customer-product-process-resources views. The usefulness of the proposed framework is exemplified by using it to derive system dynamics model of the mass customization paradigm. A discussion of the managerial implications of the obtained results for both the sustainability and the case of Small-to-Medium Enterprises (SMEs) is offered at the end of the paper.
\end{abstract}

Keywords: industry 4.0; manufacturing efficiency; mass customization; value creation; sustainability; system dynamics

\section{Introduction}

Global dynamic competition-a result of always increasing customer demands-impose a series of business challenges:

- To operate with high levels of flexibility, efficiency and adaptability in the face of product and process complexity [1].

- To fast develop, design, and manufacture high quality, low cost, smart, mass customized products [2,3], at a reasonable cost and with reduced energy and resources consumption [4].

- To use virtual and physical structures that allow the management of the whole value-chain in an agile and responsive manner [5].

These challenges require companies to be smarter and more efficient (in order to increase their operational effectiveness) and to develop new business models [6]. In this scenario, the business enterprises' survival demands the ability to react (efficiently and reliably) to rapid product changes and disturbances through re-configurability [7], through the intensive use of automation, computer systems and software [8]. These are the main features related to Industry 4.0, a concept that is becoming very popular among organizations [9], especially for its implications for the sustainability of an organizations [10]. Industry 4.0 deals with the real time availability of all relevant information involved in the value creation process and the interconnection between human beings and machines in 
a cyber-physical system [11-13]. This is done by combining manufacturing, automation, information, computing, communication, and control technologies, in order to establish an interconnected industrial value creation process $[14,15]$. Appendix A presents a brief review of some other initiatives related to the concept of Industry 4.0, with the idea of providing the reader with a way to contrast the pros and cons of the Industry 4.0 initiative. The key elements behind the idea of Industry 4.0 can be identified as follows $[2,16,17]$ :

(a) the optimization of the value chains; that is, the horizontal integration of products and stakeholders.

(b) the implementation of a virtual network of autonomous, self-controlling, self-configuring, knowledge-based, sensor-equipped, manufacturing resources.

(c) the interchange of data in and between the different phases of a product life cycle.

The purpose is achieving high levels of stability, performance, reliability, robustness, and efficiency of the physical transformation systems. This implies giving the customer the constant opportunity to become part of the value creation process through the development of tailored services [17], requiring not only the grouping together of companies and value creation functions [18-20] but also the development of new value creation mechanisms, that is, new business models [16,21]. Moreover, Industry $4.0^{\prime} \mathrm{s}$ goal is sustainable success in a mass customization market [22], where customers increase variant diversity [23] designed to their individual specifications [16,24] and without paying a high price premium [25]. Within this context, the future of an enterprise competing within an Industry 4.0, mass customization environment, depends on their sustainability, where the latter can only be achieved by the manufacturing efficiency of the smart factory-based Industry 4.0 transforming processes $[16,26,27]$. For this reason, the next section reviews the structural elements that influence it (manufacturing performance), as well as the relationship between sustainability, Industry 4.0 and value creation. Derived from this literature review, we proceed to define the research features, that is: (1) to identify the research gaps and opportunities; (2) to enunciate the research proposal (3) to establish the proposed research methodology; and (4) to highlight the research originality, usefulness and contributions.

\section{Literature Review}

\subsection{Sustainability \& Industry 4.0}

Sustainability has been often linked with Industry 4.0. References [28-30] review opportunities in Industry 4.0 for achieving sustainability, while References [31,32] consider that Industry 4.0 has clear implications for sustainability in organizations. When analyzing the pillars of Industry 4.0, we find that, regarding the use of CPS-based, smart manufacturing systems, Reference [33] mentions sustainability as one of the three main requirements of an smart factory. Reference [34] contends that a smart factory would help implement the sustainable production mode to cope with global challenges. Reference [35] presents sustainability as one of six pillars considered to be important in setting up smart facilities, upon which an Industry 4.0 environment is based. References [36,37], and [38] state that a promise of Industry 4.0-through the use of the so-called smart manufacturing systems-is that it will make it possible to achieve higher agility, productivity, and sustainability levels. Regarding the use of Internet of Things (IoT) and Big Data, References [39-41], and [42] discuss the importance that Big Data Analytics has in supply chain sustainability. The introduction of the internet of things (IoT) promotes innovation, customization, knowledge sharing and sustainability in a global context, according to References [43,44]. Big data in conjunction with IoT enables cleaner [45] and more sustainable production [41]. Regarding the use of Virtual Reality (VR) and Augmented Reality (AR), they can lead to sustainability and better training and knowledge [46]. Regarding the use of a cloud manufacturing platform, the use of a cloud platform by Industry 4.0 allows the intelligent management of the shared resources and services required to carry out an efficient collaborative production and, with this, the achievement of industrial benefits such as lower production costs and high levels of productivity and sustainability [45]. 


\subsection{Sustainability \& Value Creation}

The value and sustainability of a business is determined by its revenue model, which answers the question of how a company earns money [47]. In fact, Reference [48] considers sustainability to be one of the elements of a business model. Now, according to Reference [49], sustainability is a business feature of Industry 4.0. However, Industry 4.0 does not explicitly tackle sustainability issues and only does it when its benefits also have an economic benefit [17]. On the other hand, the sustainability issue and its link with Industry 4.0 has been discussed from a business modelling perspective in References [28,29]. Reference [50] suggests there is a need to develop innovative business models that guarantee sustainability. As early as 2004, Reference [47] mentioned that having a business model ontology to hand that describes the essential building blocks and their relationships would make it easier for managers to design a sustainable business model. In this same context, Reference [17] reviews sustainable business models in Industry 4.0, understanding this last as the "how to run a company" in a sustainable way. The work of Reference [30] identifies opportunities for Industry 4.0 that can result in sustainable business models but it does not explicitly explain how this is achieved. Reference [51] reports that there is no qualitative assessment of the contribution of Industry 4.0 to sustainable value creation. Reference [17] proposes a research agenda which includes the development of sustainable value propositions for Industry 4.0 and the development of cost-benefit analysis/revenue models for Industry 4.0 supporting sustainability.

\subsection{Sustainability \& Manufacturing Efficiency}

According to Reference [52], there is a need to take into account the strategic level and operational levels of a manufacturing organization, as both of them are interdependent: the strategic level decision-making has a deep impact at the operational level and the correct management of the operational level has a big impact on the efficiency of the strategic level. This efficiency has to do with the better use of resources by the transformation process [17]. So, even though strategic issues are important for achieving responsiveness to market changes, they are not sufficient without achieving responsiveness at the operational level. The Customer-Product-Process-Resource (CPPR) framework - proposed by Reference [53], Figure 1—allows the addressing of these through a set of within-and-among alignment conditions necessary for linking the strategic and operational levels [54], expressed in terms of configuration attributes that, in turn, allows the establishment of the documents that promote proper manufacturing execution and, with this, efficient performance [55]. If we consider that the strategic-operational alignment factor affects the performance of a manufacturing organization [56], then it becomes necessary to take it into account in order to reach high levels of sustainability (by avoiding poor efficiency in both managerial and transformation processes). 


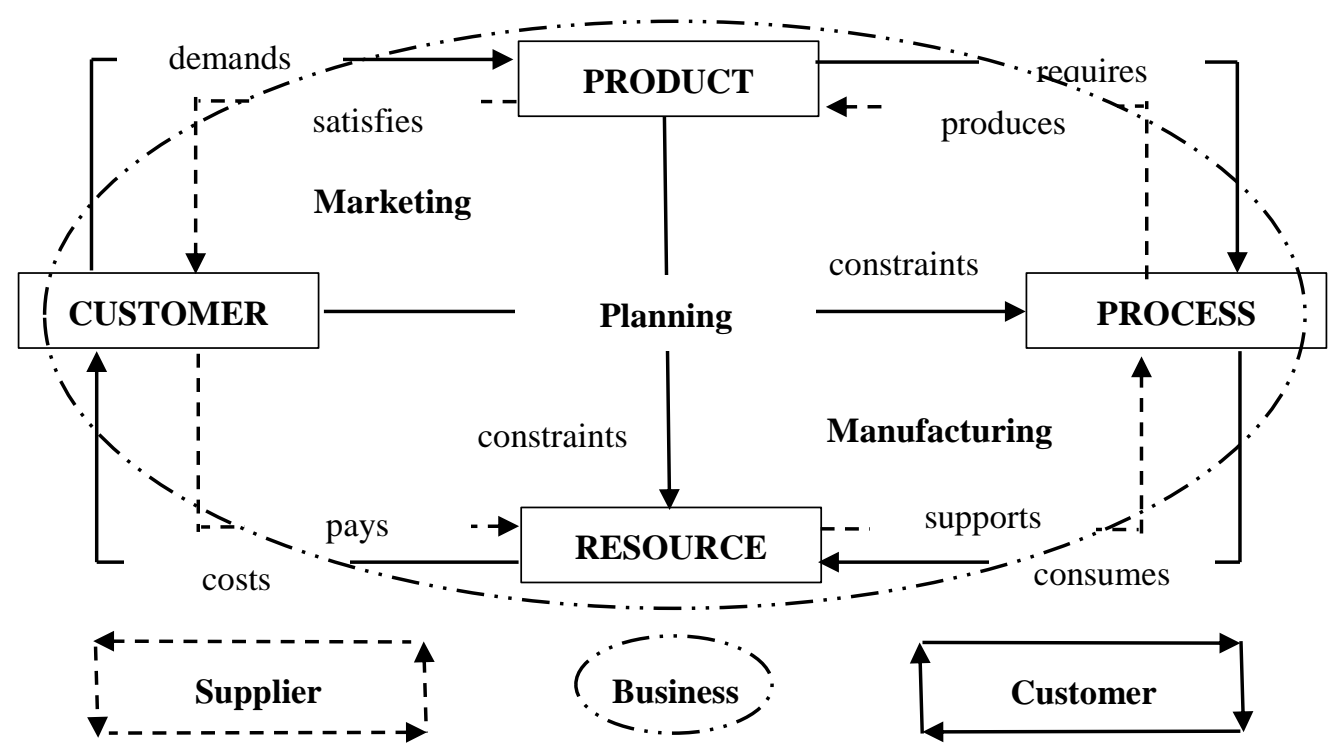

Figure 1. The Customer-Product-Process-Resource (CPPR) framework [53].

\section{Research Features}

Table 1 summarizes the contribution of the authors presented in this literature review. From the previous presented literature review we can conclude that:

(1) Sustainability is understood as a potential benefit of the implementation of the Industry 4.0 paradigm, the use of high efficiency systems being its main sustainability feature, according to Reference [57]. From here comes the need to establish the achievement of sustainability in the context of manufacturing efficiency.

(2) Sustainability is a must-element of the business models used by Industry 4.0. From here comes the need to develop business models that are sustainable.

Table 1. Literature review summary table.

\begin{tabular}{cc}
\hline Topic Addressed: Sustainability and ... & References \\
\hline Industry 4.0 links, opportunities, and implications & {$[28-32]$} \\
Smart Manufacturing & {$[33-38]$} \\
Big Data Analytics & {$[39-45]$} \\
Virtual/Augmented Reality & {$[45,46]$} \\
Business economic benefits & {$[47-49]$} \\
Business Models & {$[17,28-30,47,50-52]$} \\
Manufacturing efficiency & {$[53-56]$} \\
\hline
\end{tabular}

In order to address these identified research gaps, we state our research objective to be the development of a framework that establishes the value proposal-creation-capture cycle in the context of the strategic/operational levels that affect overall manufacturing efficiency within a manufacturing organization. The theoretical foundation of the proposed framework (referred to as the CPPR 4.0 throughout the rest of the document as) was established following a approach similar to the one used in References [58-60] when building a reference model-where a "best of breed" approach was followed by combining and integrating academia initiatives, identified via the analysis of existing literature. This required the review of the literature in the area of: (1) business models; and (2) value creation within an Industry 4.0 environment (referred to as value creation 4.0 throughout the rest of the document), and the mapping of the mapping of the findings into the CPPR framework. The originality of the work is on the approach followed, where concepts that have never been put together 
before are combined and formally integrated [61,62]. The usefulness of the proposed framework is demonstrated by using it to derive a system dynamics model of the mass customization paradigm (within an Industry 4.0 environment). The original contributions of the present paper are the proposed framework and the derived system dynamics model.

\section{Theory Foundation of the CPPR 4.0}

\subsection{Business Models}

According to Reference [47], a business model is a representation of how a company buys and sells goods and services and earns money. They answer questions like, who are customers, what to offer them, and how to operate to create value in profitable/sustainable way [1]. Authors of References [63-67] propose three interconnected value domains of a business model: Value proposition (reason why customers turn to one company over another), Value creation (resources, capabilities, and processes required to deliver the value proposition), and Value capturing (cost structure and revenue formula, which defines the profitability and economical sustainability of the business enterprise). As there is as an enormous value to management to have a software-based version of a business model, References $[47,68,69]$ introduced its Business Model Canvas (BMC), composed of nine elements divided into four categories: Product (what? or value proposition domain), Customer interface (who? or value creation domain), Infrastructure (how? or value creation domain), and Financials (value capturing domain). The reader is encouraged to consult these references for a more detailed explanation.

\subsection{Value Domains}

According to Reference [47], value domains are the interconnected value-related elements of a business model, namely value proposition, creation, and capturing. It has been stated that business enterprises compete against each other's through their value propositions [70], where their business models must change its view its focus from "what to offer" to "what value the offer brings for the customer" [71]. Now, the primary function of any business enterprise is the creation (and maintain) of value [72], something pivotal for firm survival [19], where traditionally it has been considered a financial measure [73], in the sense that product A creates more value than product B, if it has a lower price, provides more benefit, satisfaction, and/or a better experience [74]. Finally, a firm's survival on the long term requires not only the value creation but also value capturing/appropriation [75]. In this context, References [20,76-79], and [80] mention four factors that create value for a product, service, or combination of both: Product (what should be produced/offered?), Process (how should it be produced?), Equipment (by what means should it be produced?), and People \& Organization (when/where should it be produced and who should produce, supervise and manage?).

\subsection{Business Models/Value Creation 4.0}

Within the context of this document, we define the term "value creation 4.0" as the value creation process within an Industry 4.0 context. According to References [81,82], in order for Industry 4.0 to have implications for industrial core value creation, it is necessary to develop (1) new value creation business models [81], and (2) a platform-based cooperation that promotes the personalized service/product offer in real time. These new business models emerging from the integration of technological innovations [13], are expected to have a focus on the creation of value from data generated data from the end-users (customers) $[63,83,84]$, so they need to be designed around the business logic of highly customized and differentiated, well-synchronized product-service combinations $[20,84,85]$. The more cooperative environment provided by Industry 4.0 is transforming the current methods of value creation [13], where the "anywhere, anytime" ability to gather information through all the product lifecycle allows value creation not only from product selling/service offering a service but also from exploiting the available data [17]. In this context, the four "P" elements of value creation mentioned by Reference [20] can be characterized in terms of smart customers, products, processes, and resources [86]. According 
to Reference [16], these four elements are the basis of a smart factory, defined by Reference [86], as a flexible, intelligent, and highly optimized (in terms of waste, defect, and, downtime) productive manufacturing system where people, systems and objects communicate with each other, through the IoT. This is the type of manufacturing environment necessary to address the global economic mass customization pressures [17], where the ultimate objective is the real time coordination and optimization of the production stages, so customized products can be manufactured at the costs of mass production $[56,87]$.

\subsection{Mapping Value Domains into the CPPR Framework}

Based on the identified similarities between Osterwalder 's Business Model Canvas [68], Seliger's value creation factors [76] and Stocka's value creation elements [51], we propose representing the value domain in terms of representative elements, main goals, and building blocks (Table 2, the first original contribution of this research effort). Further on, based on the stated features of the CPPR framework, in this research document we propose the development of the CPPR 4.0 framework, which reflects the particular features of the Industry 4.0 value domains (established in Table 2) and that can be used to address the challenges of both the strategic and operational goals:

- Strategic level; to establish the conditions under which the whole cycle of value creation-that is, what should be offered, when/where/how/with what/by whom should it be produced and how to profit from what is to be offered-can take place (understanding the value creation process in terms of a value chain).

- Operational level; to establish the conditions under which self-awareness, self-negotiating, and self-improving capabilities of products, processes, and resources respectively, can take place in terms of an information reference model.

Figure 2 shows our proposal of the CPPR 4.0 framework (the first original contribution of this research effort). It contains the particular features of the Industry 4.0 value domains (established in Table 2), distributed into four value domains sectors (one for value proposition, one for value capturing, and two for value creation). Now, regarding these sectors, the following must be mentioned:

- Value proposition sector; three tools for building value propositions are Barne's Value Proposition Builder [70], Osterwalder 's Value Proposition Canvas [68], and Wildevuur's People Value Canvas [88].

- Value creation sector; describes the way value is created, and according to Reference [89] this can take the form of value chains (where value is created by transforming input factors into products/services), value shops (where value is created by solving a customer problem), and value networks (where value is created by mediating and coordinating relationships between network of people).

- Value capturing sector; according to Reference [75], value capturing can be performed in three forms: monetary (i.e., increase the per unit net profit by matching the price with the value offering), relational (i.e., increase customer retention, use the network partners' fullest potential) and learning (i.e., co-create knowledge through collaboration with external stakeholder).

As this research effort is a work in progress, we are interested in presenting the usefulness of the CPPR 4.0 framework, as a first step, at the strategic level. More specifically, we are interested in showing how this last can be used to develop a system dynamics model of the mass customization paradigm. 
Table 2. Industry 4.0 value domains: representative elements, goals, and building blocks.

\begin{tabular}{|c|c|c|c|c|c|c|c|c|}
\hline \multirow[b]{2}{*}{ Value Domain } & \multirow[b]{2}{*}{ Question } & \multirow[b]{2}{*}{ Element } & \multicolumn{3}{|c|}{ Strategic Level } & \multicolumn{3}{|c|}{ Operational Level } \\
\hline & & & Description & Main Goal & $\begin{array}{l}\text { Building } \\
\text { Blocks }\end{array}$ & Description & Main Goal & Building Blocks \\
\hline Value capture & $\begin{array}{l}\text { "How to profit from } \\
\text { what is to be }\end{array}$ & Customer & $\begin{array}{l}\text { Money generated } \\
\text { based on the value }\end{array}$ & $\begin{array}{c}\text { To profit in a } \\
\text { sustainable way from }\end{array}$ & $\begin{array}{l}\text { Cost structure } \\
\text { Revenue model }\end{array}$ & $\begin{array}{c}\text { customers' } \\
\text { needs/behaviors }\end{array}$ & $\begin{array}{l}\text { to provide } \\
\text { sustainable } \\
\text { purducts/gervices }\end{array}$ & $\begin{array}{l}\text { customers' access to value } \\
\text { creation networks }\end{array}$ \\
\hline $\begin{array}{l}\text { Value } \\
\text { proposition }\end{array}$ & $\begin{array}{l}\text { produced /offered?" } \\
\text { "What should be } \\
\text { produced/offered?" }\end{array}$ & Product/ Service & $\begin{array}{l}\text { creation } \\
\text { Products/Services } \\
\text { offered to the market }\end{array}$ & $\begin{array}{l}\text { value creation } \\
\text { To obtain solutions } \\
\text { that create value }\end{array}$ & $\begin{array}{l}\text { Value } \\
\text { proposition }\end{array}$ & $\begin{array}{l}\text { real-time analysis } \\
\text { self-aware products }\end{array}$ & $\begin{array}{l}\text { products/services } \\
\text { autonomous } \\
\text { decision-making }\end{array}$ & $\begin{array}{l}\text { embedded } \\
\text { internet-communication } \\
\text { sensors/microchips }\end{array}$ \\
\hline \multirow[t]{2}{*}{ Value creation } & $\begin{array}{l}\text { "When/Where/How } \\
\text { should it be } \\
\text { produced/offered?" }\end{array}$ & Process & \multirow{2}{*}{$\begin{array}{c}\text { Processes/Resources } \\
\text { required for vale } \\
\text { delivery }\end{array}$} & $\begin{array}{l}\text { To promote/facilitate } \\
\text { the value creation } \\
\text { flow }\end{array}$ & $\begin{array}{l}\text { Internal } \\
\text { processes } \\
\text { External } \\
\text { processes }\end{array}$ & $\begin{array}{l}\text { self-negotiating } \\
\text { customer orders }\end{array}$ & $\begin{array}{c}\text { decentralized } \\
\text { decision-making }\end{array}$ & $\begin{array}{l}\text { autonomous operations } \\
\text { optimization systems }\end{array}$ \\
\hline & $\begin{array}{l}\text { "With what/By whom } \\
\text { should it be } \\
\text { produced/offered?" }\end{array}$ & Resource & & $\begin{array}{c}\text { To enhance the } \\
\text { capabilities required } \\
\text { to support the value } \\
\text { creation flow }\end{array}$ & $\begin{array}{l}\text { Value } \\
\text { configuration } \\
\text { Partnerships } \\
\text { Capability } \\
\end{array}$ & $\begin{array}{l}\text { self-improving } \\
\text { resources }\end{array}$ & $\begin{array}{c}\text { intelligent } \\
\text { decision-making }\end{array}$ & $\begin{array}{l}\text { self-organization and } \\
\text { adaptiveness } \\
\text { abilities/capabilities }\end{array}$ \\
\hline
\end{tabular}




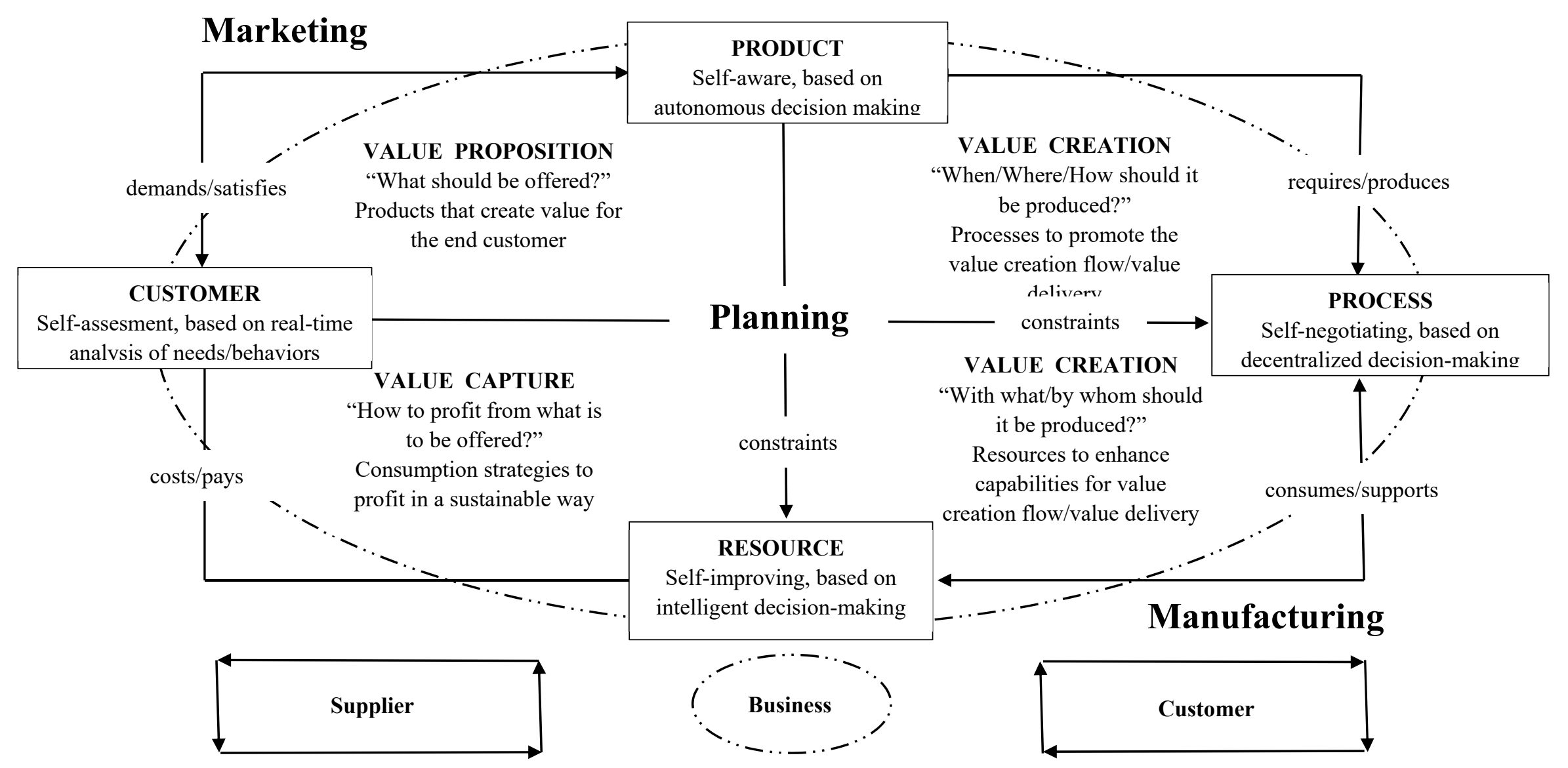

Figure 2. The CPPR 4.0 framework. 


\subsection{Practical Use of the CPPR 4.0}

The CPPR configuration attributes (see Reference [56] for more details) were mapped into the context of the mass customization paradigm (Table 3). From here, a casual loop diagram (CLD) was derived (Figure 3) using the following reasoning:

- Relationship \#1: as the level of customization increases, the level of the product's complexity increases.

- Relationship \#2: as the level of customization increases, the level of OW/OW increases.

- Relationship \#3: as the level of OW/OW increases, the level of production variety increases.

- Relationship \#4: as the level of product's complexity increases, the level of production volume decreases.

- Relationship \#5: as the level of system's reconfiguration increases, the level of production volume increases.

- Relationship \#6: as the level of system's reconfiguration increases, the level of production variety increases.

- Relationship \#7: as the level of production variety increases, the level of components/raw materials increases.

- Relationship \#8 and \#9: as the level of technification and level of labor skill increase, the level of the system's reconfiguration increases.

Table 3. Mass customization configuration attributes.

\begin{tabular}{ccc}
\hline Element \# & CPPR Context & Mass Customization Context \\
\hline 1 & Level of required customer feedback & Level of customization \\
2 & OW/OQ ratio & Level of OW/OQ \\
3 & Number of operations/components & Level of product's complexity \\
4 & Level of production volume & Level of production volume \\
5 & Level of product variety & Level of production variety \\
6 & Level of technology specialization & Level of technification \\
7 & Level of labor skills & Level of labor skill \\
8 & Level of process flexibility & Level of system's reconfiguration \\
9 & Level of raw material requirements & Level of components/raw materials \\
\hline
\end{tabular}

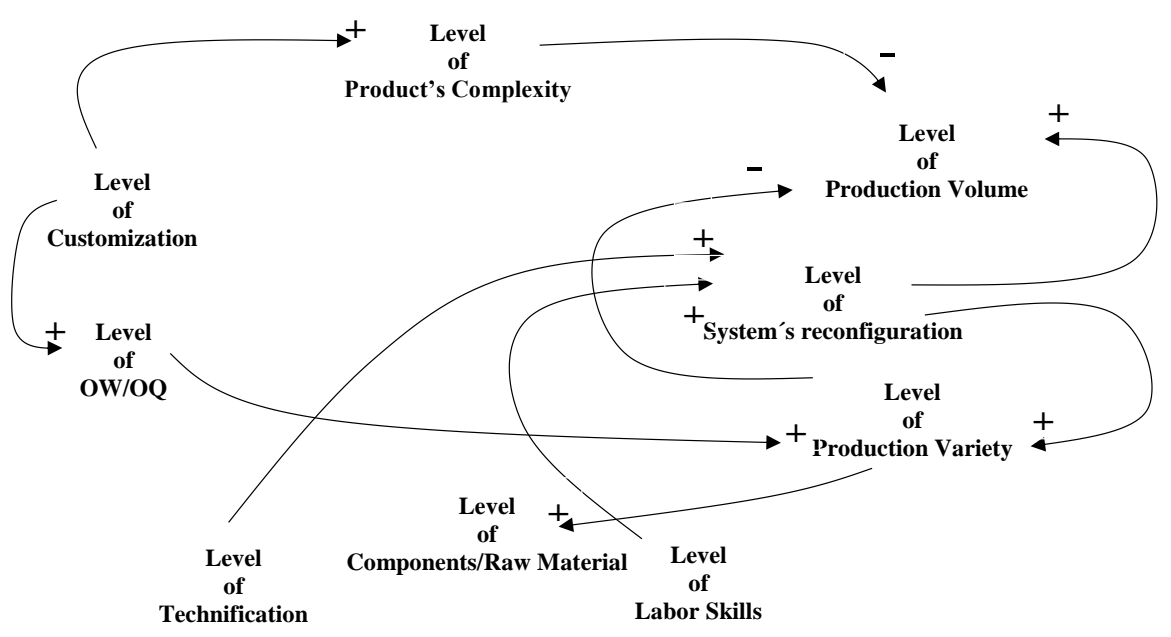

Figure 3. Mass customization paradigm casual loop diagram (CLD).

The next step taken was the development of a system dynamics model (Figure 4) using the Stella software (www.iseessytems.com). The purpose of the system dynamics model is the analysis of the Production Volume that can be achieved for a combination of different Level of Customization and Level of System's Reconfiguration values. 


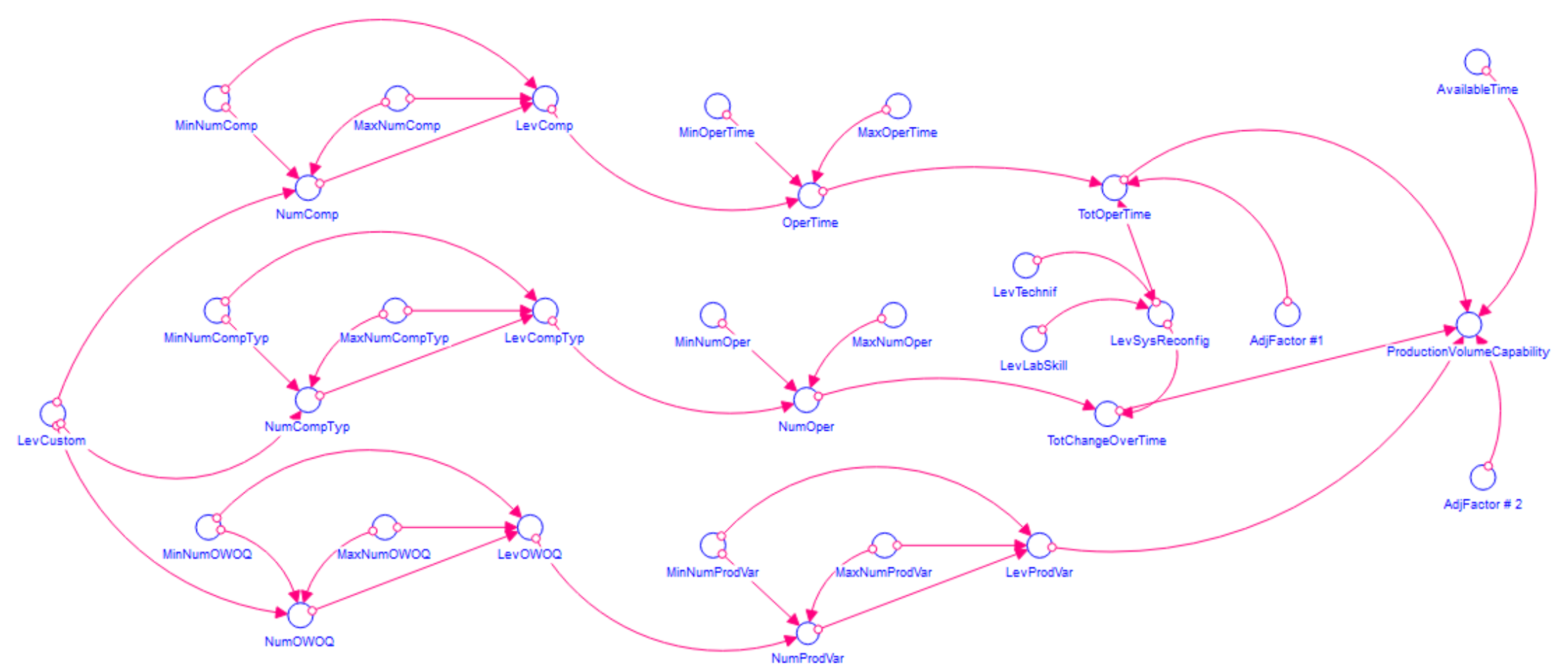

Figure 4. Stella Model of the CPPR 4.0 casual loop diagram. 
Appendix B explains the logic behind the equations used in this model. Five different runs were conducted for the duration of thirty periods in each case. Figure 5a-e present the results obtained: Series 1 (solid line) reflects the Level of System Reconfiguration; Series 2 (dashed line), the Level of Customization; and Series 3 (double line), the normalized Production Volume values. In each of these figures, the normalized Production Volume values are organized from higher to lower values. An analysis of Figure 5a-e reveals the following:

- For Figure 5a; the Level of System Reconfiguration trend line is over the Level of Customization trend line for the first ten simulation runs (with a slow close of the gap). Then, both trend lines intersect four times, in the span of four simulation runs (11-15). After this, the opposite situation takes place. This results in a Production Volume trend line with a slope of $[0.5 /(30-2)]=0.017$

- For Figure 5b: the Level of System Reconfiguration trend line is over the Level of Customization trend line for the first eleven simulation runs (with a sudden close of the gap). Then, both trend lines intersect six times, in the span of ten simulation runs (11-21). After this, the opposite situation takes place. This results in a Production Volume trend line with a slope of $[1.0 /(30-1)]=0.034$

- For Figure 5c: the Level of System Reconfiguration trend line is over the Level of Customization trend line for the first five simulation runs (with a sudden close of the gap). Then, both trend lines intersect five times in the span of ten simulation runs (5-15). After this, the opposite situation takes place. This results in a Production Volume trend line with a slope of $[0.7 /(30-3)]=0.025$

- For Figure 5d: the Level of System Reconfiguration trend line is over the Level of Customization trend line for the first nine simulation runs (with a slow close of the gap). Then, both trend lines intersect four times in the span of nine simulation runs (9-18). After this, the opposite situation takes place. This results in a Production Volume trend line with a slope of $[0.4 /(30-3)]=0.014$

- For Figure 5e: the Level of System Reconfiguration trend line is over the Level of Customization trend line for the first eight simulation runs (with a sudden close of the gap). Then, both trend lines intersect four times in the span of ten simulation runs (8-18). After this, the opposite situation takes place. This results in a Production Volume trend line with a slope of $[0.5 /(30-4)]=0.019$

A summary of these results is presented in Table 4, where each row represents the range of differences $\left(\Delta_{1}\right)$ between the values of Level of System Reconfiguration and the Level of Customization, and each column represents the range of decrease $\left(\Delta_{2}\right)$ in the normalized Production Volume value. From this table, we observe the following:

(1) The $\Delta 1$ which impacts the most $\Delta 2$ (that is, the highest value in each column), starts decreasing until $\Delta 1$ becomes negative, when it starts increasing again (i.e., for $\Delta 2=1.00-0.5$ corresponds $\Delta 1$ $=0.6-0.4$, decreasing to $\Delta 1=0.2-0.0$ for $\Delta 2=0.38-0.30$, only to increase again to $\Delta 1=-0.4-$ -0.6 for $\Delta 2=0.16 \rightarrow 0.12$ ).

(2) The impact of $\Delta 1$ has on $\Delta 2$ is not symmetrical, i.e., the impact of $\Delta 1=0.6-0.4$ is $\Delta 2=1.00-0.5$ $(50 \%)$, where the impact of $\Delta 1=-0.4--0.6$ is $\Delta 2=0.16-0.12(4 \%)$.

In other words, these results suggest that the impact of the Level of System Reconfiguration has on the Production Volume is bigger than the impact the Level of Customization has. In a context where Industry 4.0 only tackles sustainability issues when the latter has an economic benefit [17], these results support the idea that high levels of sustainability—through a higher productivity—can be achieved by investing in better technology without sacrificing the customers' preferences, one step further towards the development of a sustainable value proposition. 


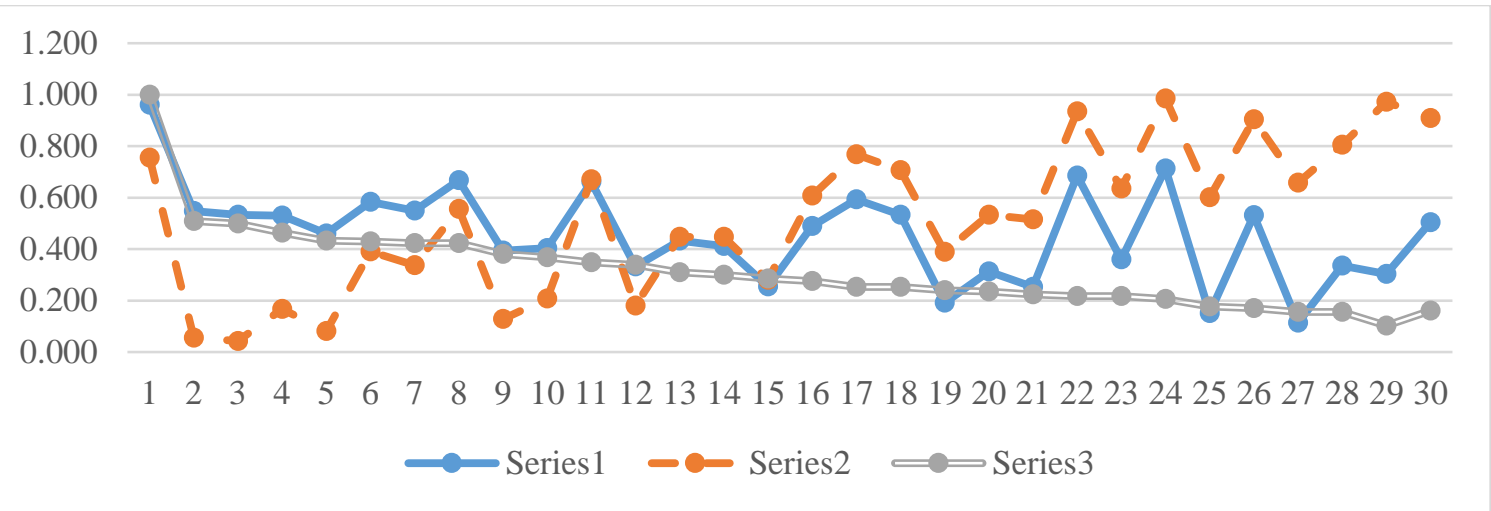

(a)

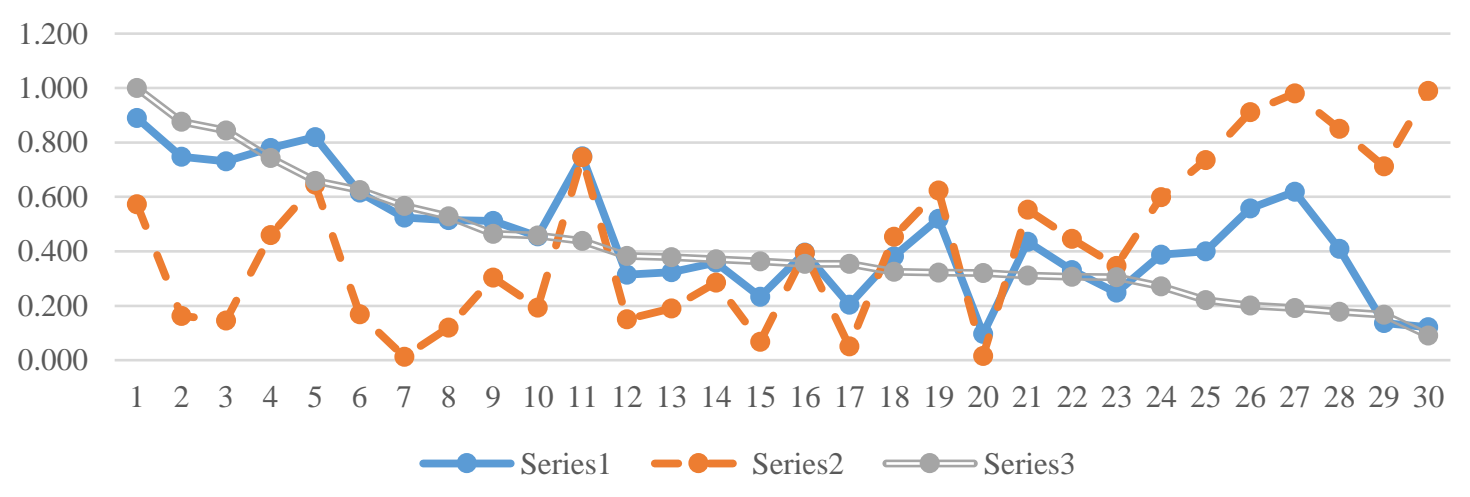

(b)

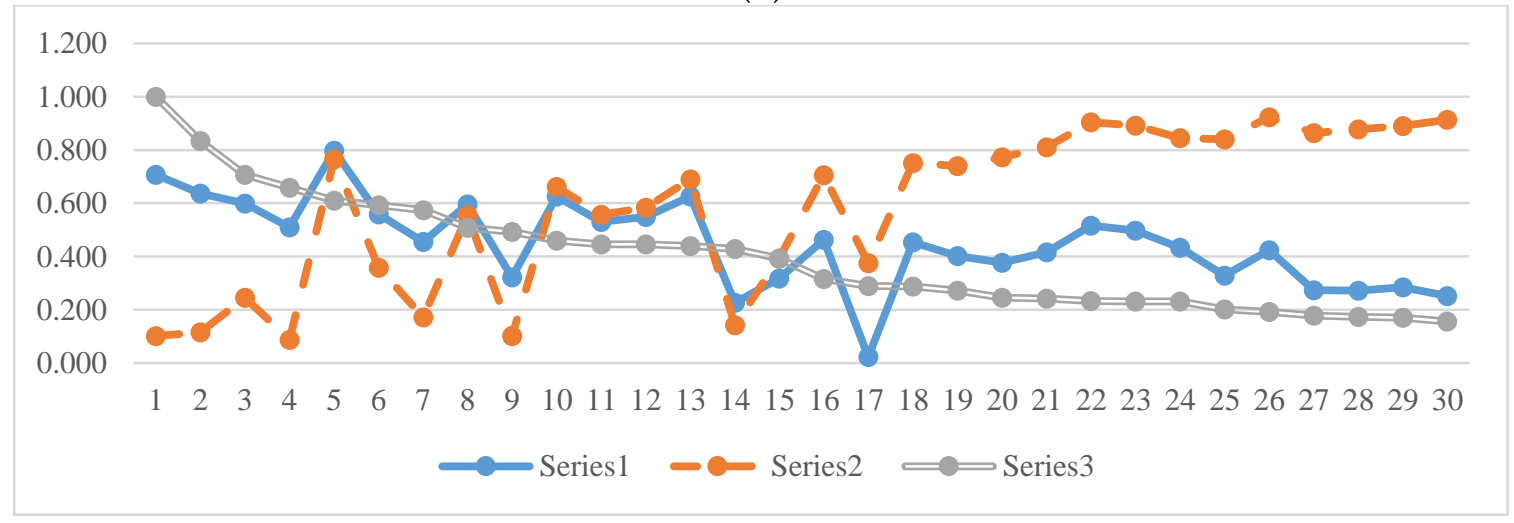

(c)

Figure 5. Cont. 


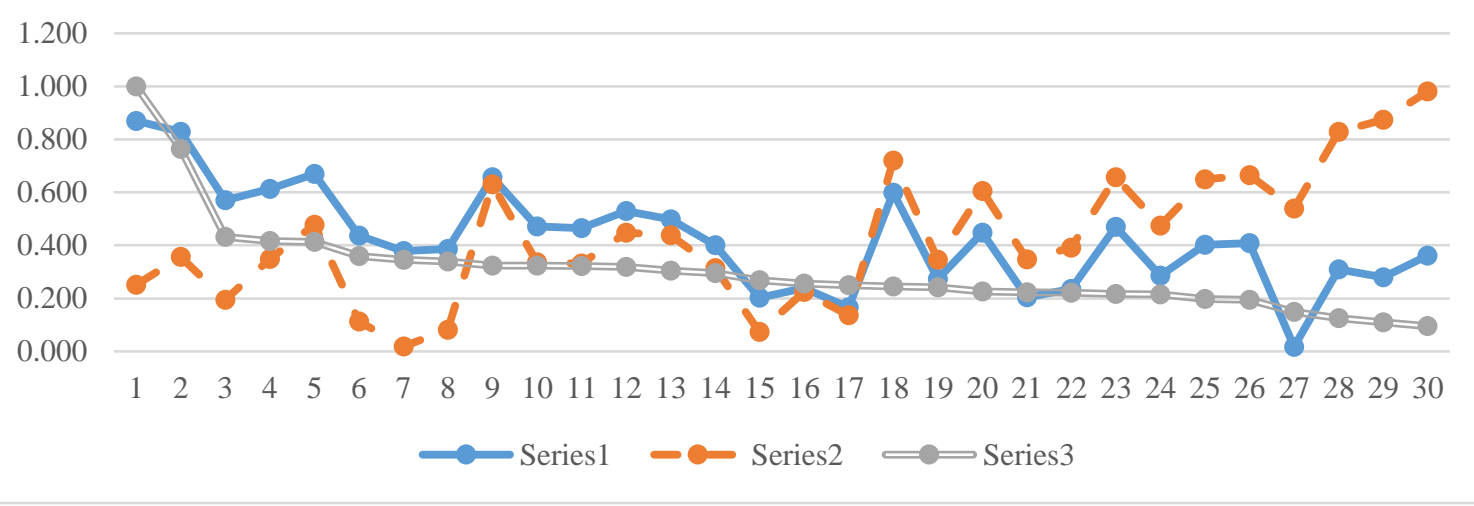

(d)

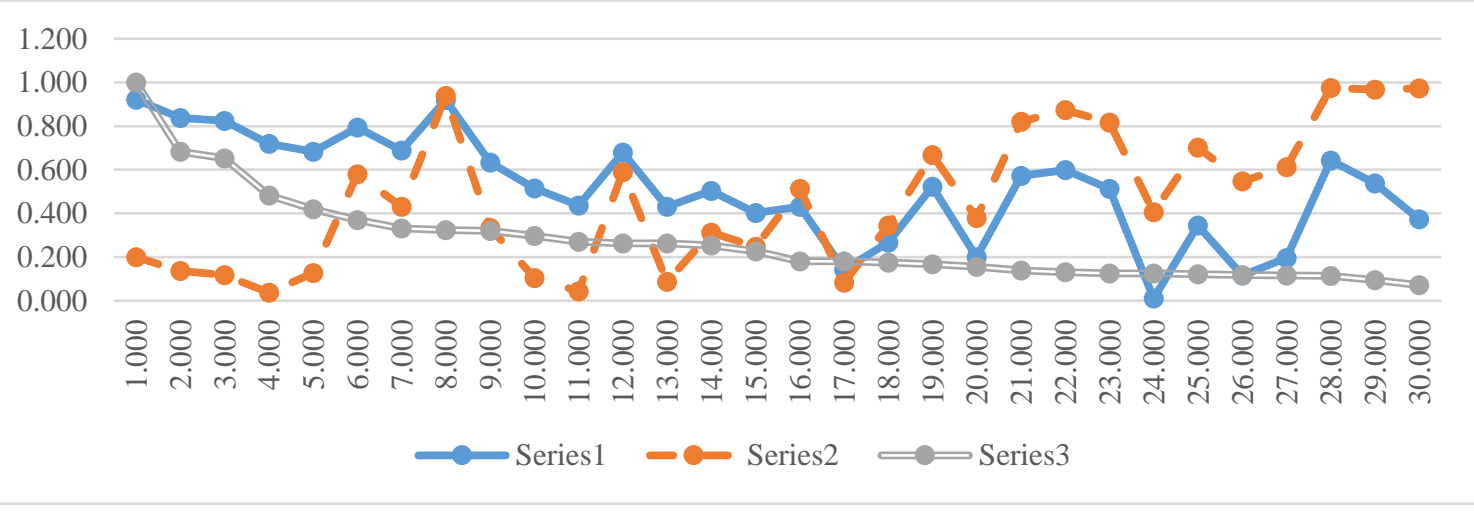

(e)

Figure 5. (a) Run \# 1; (b) Run \# 2; (c) Run \# 3; (d) Run \# 4; (e) Run \# 5.

Table 4. Impact of the Level of System Reconfiguration and Level of Customization on the normalized Production Volume values (the bolded percentage within each $\Delta_{2}$ column identify the highest $\Delta_{1}$ interval).

\begin{tabular}{|c|c|c|c|c|c|c|}
\hline \multirow[b]{2}{*}{$\Delta_{1}$} & \multicolumn{6}{|c|}{$\Delta_{2}$} \\
\hline & $\begin{array}{c}1.00-0.5 \\
(50 \%)\end{array}$ & $\begin{array}{c}0.5-0.38 \\
(12 \%)\end{array}$ & $\begin{array}{c}0.38-0.30 \\
(8 \%)\end{array}$ & $\begin{array}{c}0.30-0.24 \\
(6 \%)\end{array}$ & $\begin{array}{c}0.24-0.16 \\
(8 \%)\end{array}$ & $\begin{array}{c}0.16-0.12 \\
(4 \%)\end{array}$ \\
\hline $0.8->0.6$ & $24 \%$ & & & & & \\
\hline $0.6->0.4$ & $32 \%$ & $8 \%$ & & & & \\
\hline $0.4->0.2$ & $28 \%$ & $56 \%$ & $8 \%$ & & & \\
\hline $0.2->0.0$ & $12 \%$ & $28 \%$ & $60 \%$ & $24 \%$ & & \\
\hline $0.0->-0.2$ & $4 \%$ & $8 \%$ & $32 \%$ & $52 \%$ & $28 \%$ & \\
\hline$-0.2->-0.4$ & & & & $24 \%$ & $60 \%$ & $20 \%$ \\
\hline$-0.4->-0.6$ & & & & & $12 \%$ & $52 \%$ \\
\hline$-0.6->-0.8$ & & & & & & $28 \%$ \\
\hline
\end{tabular}

\subsection{Managerial Implications for Small-to-Medium Enterprises (SMEs)}

The Small-to-Medium enterprises' (SMEs) impact on value creation and their importance for the overall economy is a topic that has been reported frequently in the literature. SMEs are considered a backbone of the economy because of their strong position as employers [1]. They play an important role in the overall network of industrial value creation: in the European Union, they represent over 99.6\% of all companies (in the case of Germany, 95\%); employ between 50 and 70\% of all European full time equivalents; generate a gross value added share that encompasses about $50 \%$ of the European economy [15]. Within this scenario, there is a lack of fundamental knowledge about how SMEs could 
successfully participate in an Industry 4.0 environment, especially when dealing with some of the following situations:

- They may have some trouble implementing new technologies and also in modifying and adapting their business models [1].

- It is not easy for them to implement an Industry 4.0 strategy as it is difficult to join a value chain using standards and norms different from ones they currently use [90].

- They struggle to obtain the resources/knowledge required to establish the new value creation business models required to successfully implement Industry 4.0 [15].

- They have the common perception that, due to their limited capital availability and lack of expertise, advanced automation is reserved to big industrial players, which results in an adoption lethargy [91].

- They struggle with adopting and implementing Industry 4.0 solutions, as there is a lack of awareness of the link between business and technological worlds on the strategic and tactical levels within the company [92].

It is our belief that the proposed CPPR 4.0 framework could be used as a blueprint to derive a sustainable value creation business model that combines the features of SMEs and the mass customization paradigm and which takes into account the link of the strategic and tactical levels of the organization. For example, a discrete-event simulation version of the system dynamics model could be developed and used as a what-if scenario testing tool, so the proper balance between capital investment and sustainable profitability can be assessed.

\section{Conclusions and Future Research}

International global dynamic competition imposes a series of challenges on business enterprises. These challenges require companies to mature into something smarter and more efficient and ton develop new business models. The main features related to the Industry 4.0 concept-which is becoming much popular among manufacturing organizations-are regarded to be the response to the challenges of this current global competition. Within this context, new value creation business models are needed, based on the integration of technological innovations that provide the cooperative environments necessary to promote value-creation, which does not only come from selling the product/offering a service itself, but also from exploiting the available data. In this research document, we introduced the CPPR 4.0 framework, which distributes the value proposition-capture-creation cycle of an Industry environment into four value domain sectors. As a first step in the use of the CPPR 4.0 framework for addressing the issues of an Industry 4.0 environment (at the strategic and operational levels), we showed its practical application by developing a system dynamics model of the mass customization paradigm. The obtained results seem to suggest that the impact the Level of System Reconfiguration has on the Production Volume is bigger than the impact of the Level of Customization. The implications of these results for the sustainability issue come from the fact that creating a business model with a sustainable value proposition is possible when properly addressing the use of high levels of technology. Future research will address the use of the CPPR 4.0 framework and the development of a real-time, up-to-date, operational information reference model that, according to Reference [4], is required to support the two fundamental capabilities needed to effectively address the mass customization challenge [9], that is, to simplify the customization process; to assure the key resources/activities are suitable and scalable.

Author Contributions: In this paper, C.M.-O. and J.M.-V. were responsible for the design and wrting of the whole paper. All authors have both read and approved the manuscript.

Conflicts of Interest: The authors declare no conflict of interest. 


\section{Appendix A}

According to Reference [1], the term "Industry 4.0" was first used in the 2011 Hannover Expo, where the leaders of the German Government emphasized the necessity of integrating all production processes and the close cooperation with information and communication technology (ICT) and machinery industries. As a response to this German initiative, other countries proposed their own initiatives [93]:

- The USA developed "A Strategy for American Innovation" for creating new jobs and strengthening ICT industry leadership and promoted an advanced manufacturing partnership for reviving the manufacturing industry based on the private sectors' capability of Big Data, IoT, etc. In this case, the proposal is driven by several founding members from industry rather than the government.

- The European Union (EU) initiated a program called "Factories of the Future" for sustainable production while maintaining global competitiveness.

- Japan declared the "the 4th Industrial Revolution" as a national strategy, actively utilizing its strong robotics technology in order to increase industrial competitiveness and accelerate the socio-economic system.

- China is promoting the "Made in China 2025 Plan," which represents an attempt to introduce IoT technologies within industrial value creation but with a different purpose: reaching the position of a leading industrial nation worldwide.

- The similar South Korea program aims to introduce digital technologies within industrial manufacturing is pursued under the title "Manufacturing Innovation 3.0," 14 among many further programs worldwide.

For a more into detail comparison of these initiatives, the reader can refer to Reference [94].

\section{Appendix B}

- $\quad$ LevCustom = RANDOM $(0,1)$; where a value of zero means low customization, and a value of one mean refers to high customization.

- $\quad$ MinNumComp = 1, MaxNumComp = 6; where a value of one refers to the case of products with low level of customization, and a value of six refers to products with high level of customization.

- $\quad$ NumComp $=(\operatorname{EXP}(3 \times$ LevCustom $)) \times(($ MaxNumComp-MinNumComp $) / 20.08553692)$

- $\quad$ MinNumComp; the number of components (in a certain Product ${ }_{i}$ ), is dependent of the Level of Customization, and expressed in terms of an exponential function, to reflect the fact that this number does not increase linearly as the level of customization increases.

- $\quad$ LevComp $=$ IF(NumComp = MinNumComp) THEN (0) ELSE (NumComp/MaxNumComp); the number of components is normalized between the values of zero and one.

- MinNumCompTyp =1, MaxNumCompTyp = 3; where a value of one refers to the case of products with low level of customization, and a value of three refers to products with high level of customization.

- $\quad$ NumCompTyp $=($ EXP $(3 \times$ LevCustom $)) \times(($ MaxNumCompTyp -

- MinNumCompTyp)/20.08553692)

- +MinNumComp; the number of components types (in a certain Product ${ }_{\mathrm{i}}$ ), is dependent of the Level of Customization, and expressed in terms of an exponential function, to reflect the fact that this number does not increase linearly as the level of customization increases.

- $\quad$ LevCompTyp = IF(NumCompTyp = MinNumCompTyp) THEN (0) ELSE

- (NumCompTyp/MaxNumCompTyp); the number of component types is normalized between the values of zero and one.

- $\quad$ MinNumOWOQ = 1, MaxNumOWOQ = 6; where a value of one refers to the case of products with low level of customization, and a value of six refers to products with high level of customization.

- $\quad$ NumOWOQ $=(\operatorname{EXP}(3 \times$ LevCustom $)) \times(($ MaxNumOWOQ-MinNumOWOQ $) / 20.08553692)$ 
- +MinNumOWOQ; the number of OWOQ (in a certain Product ${ }_{i}$ ), is dependent of the Level of Customization, and expressed in terms of an exponential function, to reflect the fact that this number does not increase linearly as the level of customization increases.

- $\quad$ LevOWOQ $=\operatorname{IF}($ NumOWOQ $=$ MinNumOWOQ $)$ THEN (0) ELSE

- (NumOWOQ/MaxOWOQ); the number of OWOQ is normalized between the values of zero and one.

- MinNumProdVar = 3, MaxNumProdVar = 6; where a value of three refers to the case of products with low level of OWOQ, and a value of six refers to products with high level of OWOQ.

- $\quad$ NumProdVar $=(\text { EXP }(3 \times \text { LevOWOQ }))^{*}(($ MaxNumProdVar-MinNumProdVar $) / 20.08553692)$

- +MinNumProdVar; the number of product variants is dependent of the Level of OWOQ, and expressed in terms of an exponential function, to reflect the fact that this number does not increase linearly as the level of OWOQ increases.

- $\quad$ LevProdVar $=$ IF(NumProdVar $=$ MinNumProdVar) THEN (0) ELSE

- (NumProdVar/MaxNumProdVar); the number of product variants is normalized between the values of zero and one.

- $\quad$ MinOperTime $=1$, MaxOperTime $=24$.

- OperTime $=(1-$ LevComp $) *$ MinOperTime + LevComp $*$ MaxOperTime; where the operation time increases linearly as the Level of Components increases.

- $\quad$ MinNumOper $=1$, MaxNumOper $=4$.

- NumOper $=(1-$ LevCompTyp $) *$ MinNumOper + LevCompTyp $\times$ MaxNumOper; where the operation time increases linearly as the Level of Components Types increases.

- $\quad \operatorname{LevTechnif}=\operatorname{RANDOM}(0,1), \operatorname{LevLabSkill~=~} \operatorname{RANDOM}(0,1) ;$ where a value of zero (in both cases) means low Level of Technification/Level of Labor Skills, and a value of one mean refers to a high Level of Technification/Level of Labor Skills.

- $\quad$ LevSysReconfig $=($ LevTechnif + LevLabSkill $) / 2$; the Level of System Reconfiguration is normalized between the values of zero and one (and assuming each element of the formulation has the same weight).

- $\quad$ TotOperTime $=$ OperTime $\times(1-$ LevSysReconfig $\times$ AdjFactor\# 1$)$; where the higher the Level of System Reconfiguration, the more the Operation Time can be reduced.

- AdjFactor \#1 = 0.9; this factor is introduced to limit how much the Operation Time can be reduced.

- $\quad$ TotChangeOverTime $=$ NumOper $\times(1-$ LevSysReconfig $)$; where the higher the Level of System Reconfiguration, the more the Number of Operations (representing the changeover time) can be reduced even to zero.

- AvailableTime = 100; the total amount of production time available (arbitrarily established).

- ProductionVolume $=$ AvailableTime/((TotOperTime + TotChangeOverTime $) /$

- $\quad(1-$ LevProdVar $\times$ AdjFactor\#2)); in this case, the Level of Product Variety increases the Total Operation Time.

AdjFactor \# $2=0.1$; this factor is introduced to limit how much the Total Operation Time can be increased.

\section{References}

1. Safar, L.; Sopko, J.; Bednar, S.; Poklemba, R. Concept of SME business model for industry 4.0 environment. TEM J. 2018, 7, 626-637. [CrossRef]

2. Waris, M.M.; Sanin, C.; Szczerbicki, E. Smart innovation engineering (sie): Experience-based product innovation system for industry 4.0. In Information Systems Architecture and Technology; Wilimowska, Z., Ed.; Springer: Cham, Switzerland, 2017; pp. 379-388. [CrossRef]

3. Tu, M.; Lim, M.K.; Yang, M.F. IoT-based production logistics and supply chain system-Part 2. IoT-based cyber-physical system: A framework and evaluation. Ind. Manag. Data Syst. 2018, 118, 96-125. [CrossRef] 
4. Kochan, D.; Miksche, R. Advanced Manufacturing and Industrie 4.0 for SME. In Proceedings of 5th International Conference on Advanced Manufacturing Engineering and Technologies; Lecture Notes in Mechanical Engineering; Majstorovic, V., Jakovljevic, Z., Eds.; Springer International Publishing: Cham, Switzerland, 2017; pp. 357-364. [CrossRef]

5. Schumacher, A.; Erolb, S.; Sihn, W. A maturity model for assessing Industry 4.0 readiness and maturity of manufacturing enterprises. Procedia CIRP 2016, 52, 161-166. [CrossRef]

6. Kannan, S.M.; Suri, K.; Cadavid, J.; Barosan, I.; van den Brand, M.; Alferez, M.; Gerard, S. Towards industry 4.0: gap analysis between current automotive mes and industry standards using model-based requirement engineering. In Proceedings of the IEEE International Conference on Software Architecture Workshops (ICSAW), Gothenburg, Sweden, 5-7 April 2017.

7. Tang, H.; Li, D.; Wang, S.; Dong, Z. CASOA: An architecture for agent-based manufacturing system in the context of industry 4.0. IEEE Access 2018, 6, 2018. [CrossRef]

8. Lin, D.; Lee, C.K.M.; Lau, H.; Yang, Y. Strategic response to industry 4.0: An empirical investigation on the Chinese automotive industry. Ind. Manag. Data Syst. 2018, 118, 589-605. [CrossRef]

9. Kusi-Sarpong, S.; Moktadir, A.; Ali, S.M.; Shaikh, A.A. Assessing challenges for implementing Industry 4.0: Implications for process safety and environmental protection. Process Safety Environ. Protect. 2018, 117, 730-741.

10. Junior, J.A.G.; Busso, C.M.; Gobbo, S.C.O.; Carreão, H. Making the links among environmental protection, process safety, and industry 4.0. Process Safety Environ. Protect. 2018, 117, 372-382.

11. Bitkom, E.V.; Vdma, E.V.; Zvei, E.V. Implementation Strategy Industrie 4.0: Report on the results of the Industrie 4.0 Platform; Bitkom e.V.: Berlin, Germany, 2016; ISBN 978-3-00-052211-6.

12. Tjahjonoa, B.; Espluguesb, C.; Aresc, E.; Pelaezc, G. What does Industry 4.0 mean to Supply Chain? Procedia Manufact. 2017, 13, 1175-1182. [CrossRef]

13. Ibarra, D.; Ganzarain, J.; Igartua, J.I. Business model innovation through Industry 4.0: A review. Procedia Manufact. 2018, 22, 4-10. [CrossRef]

14. Chukwuekwe, D.O.; Schjølberg, P.; Rødseth, H.; Stuber, A. Reliable, robust and resilient systems: towards development of a predictive maintenance. In Proceedings of the Concept within the Industry 4.0 Environment, Euromaintenance, Conference, Athens, Greece, 30 May-1 June 2016.

15. Müller, J.M.; Maier, L.; Veile, J.; Voigt, K.I. Cooperation Strategies among SMEs for Implementing Industry 4.0. In Digitalization in Supply Chain Management and Logistics, Proceedings of the Hamburg International Conference of Logistics (HICL)—23; Wolfgang, K., Thorsten, B., Ringle, C.M., Eds.; epubli: Berlin, Germany, 2017; ISBN 9783745043280.

16. Duarte, S.; Cruz-Machado, V. Exploring linkages between lean and green supply chain and the industry 4.0. In Proceedings of the Eleventh International Conference on Management Science and Engineering Management; Xu, J., Gen, M., Hajiyev, A., Cooke, F.L., Eds.; Springer International Publishing: Cham, Switzerland, 2018. [CrossRef]

17. Cornelis de Man, J.; Strandhagen, J.O. An Industry 4.0 research agenda for sustainable business models. Procedia CIRP 2017, 63, 721-726.

18. Sauter, R.; Bode, M.; Kittelberger, D. How Industry 4.0 is Changing How We Manage Value Creation. 2015. Available online: www.horvarth-partners.com. (accessed on 15 July 2015).

19. Ardito, L.; Petruzzelli, A.M.; Panniello, U.; Garavelli, A.C. Towards Industry 4.0: Mapping digital technologies for supply chain management-marketing integration. Bus. Process Manag. J. 2018, 25, 323-346. [CrossRef]

20. Schneider, P. Managerial challenges of Industry 4.0: An empirically backed research agenda for a nascent field. Rev. Manag. Sci. 2018, 12, 803-848. [CrossRef]

21. Foresti, F.; Varvakis, G. Ubiquity and Industry 4.0. Knowledge management in digital change. In Progress in IS; North, K., Maier, R., Haas, O., Eds.; Springer International Publishing AG, Part of Springer Nature: Cham, Switzerland, 2018. [CrossRef]

22. Latorre-Biel, J.I.; Faulín, J.; Juan, A.A.; Jiménez-Macías, E. Petri net model of a smart factory in the frame of industry 4.0. IFAC PapersOnLine 2018, 51, 266-271. [CrossRef]

23. Raza, A.; Haouari, L.; Pero, M.; Absi, N. Impacts of Industry 4.0 on the specific case of mass customization through modeling and simulation approach. In Customization 4.0; Hankammer, S., Nielsen, K., Piller, F., Schuh, G., Wang, N., Eds.; Springer: Cham, Switzerland, 2018. [CrossRef] 
24. Pfisterer, D.; Radonjic-Simic, M.; Reichwald, J. Business model design and architecture for the internet of everything. J. Sens. Actuator. Netw. 2016, 5, 7. [CrossRef]

25. Sievänen, M.; Heiskala, M.; Tiihonen, J.; Stiina Paloheimo, K.; Siirilä, T. Analyzing service mass customization business models. In Proceedings of the 4th International Conference on Mass Customization and Personalization in Central Europe (MCP-CE 2010), Belgrade, Serbia, 22-24 September 2010; pp. 72-78.

26. Yao, X.; Zhou, J.; Lin, Y.; Li, Y.; Yu, H.; Liu, Y. Smart manufacturing based on cyber-physical systems and beyond. J. Intell. Manufact December 2017, 1-13. [CrossRef]

27. Mourtzis, D.; Fotia, S.; Boli, N.; Pittaro, P. Product-service system (PSS) complexity metrics within mass customization and Industry 4.0 environment. Int. J. Adv. Manufact. Technol. 2018, 97, 91-103. [CrossRef]

28. Sun, Y.; Yan, H.; Lu, C.; Bie, R.; Thomas, P. A holistic approach to visualizing business models for the internet of things. Communicat. Mobile Comput. 2012, 1, 1-7. [CrossRef]

29. Brettel, M.; Friederichsen, N.; Keller, M.; Rosenberg, M. How Virtualization, decentralization and network building change the manufacturing landscape: An industry 4.0 perspective. Int. J. Mech. Aerosp. Ind. Mech. Eng. 2014, 8, 37-44.

30. Stock, T.; Seliger, G. Opportunities of sustainable manufacturing in industry 4.0. Procedia CIRP 2106, 40, 536-541. [CrossRef]

31. Jabbour, A.B.L.S.; Jabbour, C.J.C.; Foropon, C.; Godinho, F. When titans meet -Can industry 4.0 revolutionise the environmentally sustainable manufac-turing wave? The role of critical success factors. Technol. Forecast. Soc. Chang. 2018, 132, 18-25. [CrossRef]

32. Jabbour, A.B.L.S.; Jabbour, C.J.; Godinho, F.; Roubaud, D. Industry 4.0 and the circular economy: A proposed research agenda and original roadmap for sustainable operations. Ann. Oper. Res. 2018, 270, 273-286.

33. Yoon, J.S.; Shin, S.J.; Suh, S.H. A conceptual framework for the ubiquitous factory. Int. J. Product. Res. 2012, 50, 2174-2189. [CrossRef]

34. Wang, S.; Wan, J.; Li, D.; Zhang, C. Implementing Smart Factory of Industrie 4.0: An Outlook. Int. J. Distrib. Sens. Netw. 2016, 2016, 10. [CrossRef]

35. Kusiak, A. Smart manufacturing. Int. J. Product. Res. 2017, 56, 508-517. [CrossRef]

36. Davis, J.; Edgar, T.; Porter, J.; Bernaden, J.; Sarli, M. Smart manufacturing, manufacturing intelligence and demand-dynamic performance. Comput. Chem. Eng. 2012, 47, 145-156. [CrossRef]

37. Kang, H.S.; Lee, J.Y.; Choi, S.S.; Kim, H.; Park, J.H.; Son, J.Y.; Kim, B.H.; Noh, S.D. Smart manufacturing: Past research, present findings, and future directions. Int. J. Pr. Eng. Man. GT 2016, 3, 111-128. [CrossRef]

38. Woo, J.; Shin, S.J.; Seo, W.; Meilanitasari, P. Developing a big data analytics platform for manufacturing systems: Architecture, method, and implementation. Int. J. Adv. Manufact. Technol. 2018, 99, 2193-2217. [CrossRef]

39. Hazen, B.; Boone, C.; Farmer, L.A.; Ezell, J. Data quality for data science, predictive analytics, and big data in supply chain management: An introduction to the problem and suggestions for research and applications. Intern. J. Product. 2014, 154, 72-80. [CrossRef]

40. Hazen, B.T.; Skipper, J.B.; Ezell, J.D.; Boone, C.A. Big data and predictive analytics for supply chain sustainability: A theory-driven research agenda. Comp. Ind. Eng. 2016, 101, 592-598. [CrossRef]

41. Papadopoulos, T.; Gunasekaran, A.; Dubey, R.; Altay, N.; Childe, S.J.; Fosso Wamba, S. The role of big data in explaining disaster resilience in supply chains for sustainability. J. Clean. Product. 2017, 142, 1108-1118. [CrossRef]

42. Wu, K.J.; Liao, C.J.; Tseng, M.L.; Lim, M.K.; Hu, J.; Tan, K. Toward sustainability: Using big data to explore the decisive attributes of supply chain risks and uncertainties. J. Clean. Product. 2017, 142, 663-676. [CrossRef]

43. Yao, X.; Lian, Z.; Yang, Y.; Zhang, Y.; Jin, H. Wisdom manufacturing: New humans-computers-things collaborative manufacturing model. Comp. Integr. Manufact. Syst. 2014, 20, 1490-1498.

44. Yao, X.; Yu, M.; Chen, Y.; Xiang, Z. Connotation, architecture and key technologies of internet of manufacturing things. Comp. Integr. Manufact. Syst. 2014, 20,1-10.

45. Zhang, L.; Mai, J.; Li, B.H.; Tao, F.; Zhao, C.; Ren, L.; Huntsinger, R.C.; Ren, R.C. Future manufacturing industry with cloud manufacturing. In Cloud-Based Design and Manufacturing (CBDM); Schaefer, D., Ed.; Springer International Publishing: Cham, Switzerland, 2014. [CrossRef]

46. Mittal, S.; Khan, M.A.; Romero, D.; Wuest, T. Smart manufacturing: Characteristics, technologies and enabling factors. Proc. IMechE Part B J. Eng. Manufact. 2017, 233, 1342-1361. [CrossRef] 
47. Osterwalder, A. The Business Model Ontology: A Proposition in a Design Science Approach. Ph.D. Thesis, Universite de Lausanne Ecole des Hautes Etudes Commerciales, Lausanne, Switzerland, 2004.

48. Afuah, C.A. Internet Business Models and Strategies; McGraw Hill: Boston, MA, USA, 2003.

49. Prause, G. Sustainable business models and structures for INDUSTRY 4.0. J. Security Sustain. Issues 2015, 5, 159-169. [CrossRef]

50. Gelbmann, U.; Hammerl, B. Integrative re-use systems as innovative business models for devising sustainable product-service-systems. J. Clean. Product. 2015, 97, 50-60. [CrossRef]

51. Stocka, F.T.; Obenaus, M.; Kunz, S.; Kohl, H. Industry 4.0 as enabler for a sustainable development: A qualitative assessment of its ecological and social potential. Process Saf. Environ. Protect. 2018, 118, 254-267. [CrossRef]

52. Martinez-Olvera, C.; Davizon-Castillo, Y.A. Modeling the supply chain management creation of value: A literature review of relevant concept. In Applications of Contemporary Management Approaches in Supply Chains; IntechOpen Limited: London, UK, 2015; ISBN 978-953-51-2045-2.

53. Martinez-Olvera, C.; Shunk, D. Comprehensive framework for the development of a supply chain strategy. Int. J. Product. Res. 2006, 44, 4511-4528. [CrossRef]

54. Martinez-Olvera, C. Methodology for realignment of supply-chain structural elements. Int. J. Product. Econ. 2008, 114, 714-722. [CrossRef]

55. Martinez-Olvera, C. Reference model of the manufacturing execution activity in make-to-order environments. Int. J. Product. Res. 2007, 47, 1635-1659. [CrossRef]

56. Ivanov, D. Structural dynamics and resilience in supply chain risk management. In International Series in Operations Research \& Management Science; Springer International Publishing: Cham, Switzerland, 2018; Volume 265. [CrossRef]

57. Oztemel, E.; Gursev, S. Literature review of Industry 4.0 and related technologies. J. Intell. Manufact. 2018, 1-56. [CrossRef]

58. Hsu, C.; Rattner, L.; Pant, S. Manufacturing information using a reference model. Int. J. Operat. Product. Manag. 1994, 14, 11.

59. Hsu, C.; Rattner, L.; Cho, J.; Yee, L. Core information model: a practical solution to costly integration problems. Comp. Ind. Eng. 1995, 28, 523-544. [CrossRef]

60. Fan-Tien, C.; Yang, H.C.; Kuo, T.L.; Feng, C.; Jeng, M.D. Modeling and analysis of equipment managers in manufacturing execution systems for semiconductor packaging. IEEE Trans. Syst. Man Cybernet. Part B Cybernet. 2000, 30, 772-782. [CrossRef]

61. Malhotra, R.; Jayaraman, S. An integrated framework for enterprise modeling. J. Manufact. Syst. 1992, 11, 426-441.

62. Presley, A.; Huff, B.; Liles, D. A comprehensive enterprise architecture for small manufacturers. In Proceedings of the 2nd Industrial Engineering Research Conference, Los Angeles, CA, USA, 26-28 May 1993.

63. Kagermann, H. Change through digitization-Value creation in the age of industry 4.0. In Management of Permanent Change; Albach, H., Meffert, H., Pinkwart, A., Reichwald, R., Eds.; Springer: Berlin, Germany, 2015.

64. Johnson, M.; Christensen, C.; Kagermann, C.H. Reinventing your business model. Harvard Bus. Rev. 2008, 86, 50-59.

65. Zott, C.; Amit, R.; Massa, L. The business model: Recent developments and future research. J. Manag. 2011, 37, 1019-1042. [CrossRef]

66. Seidenstricker, S.; Rauch, E.; Battistella, C. Business model engineering for distributed manufacturing systems. Procedia CIRP 2017, 62, 135-140. [CrossRef]

67. Gerlitz, L. Design management as a domain of smart and sustainable enterprise: Business modelling for innovation and smart growth in Industry 4.0. Int. J. Entrepreneurship Sustain. Issues 2016, 3, $244-268$. [CrossRef]

68. Osterwalder, A.; Pigneur, Y.; Clark, T.; Smith, A. Business model generation: A handbook for visionaries, game changers, and challengers. Afr. J. Bus. Manag. 2011, 5, 22-30.

69. Bouwman, H.; Faber, E.; Haaker, T.; Kijl, B.; Reuver, M.D. Conceptualizing the STOF Model. In Mobile Service Innovation and Business Models; Bouwman, D.H., Vos, D.H.D., Haaker, D.T., Eds.; Springer: Berlin, Germany, 2008; pp. 31-70. 
70. Barnes, C.; Blake, H.; Pinder, D. Creating and Delivering Your Value Proposition: Managing Customer Experience for Profit; Kogan Page Limited: London, UK, 2009.

71. Kans, M.; Ingwald, A. Business model development towards service management 4.0. Procedia CIRP 2016, 47, 489-494. [CrossRef]

72. Singh, P.M.; Jonkers, H.; Iacob, M.E.; van Sinderen, M.J. Modeling Value Creation with Enterprise Architecture. In Proceedings of the 16th International Conference on Enterprise Information Systems (ICEIS-2014), Lisbon, Portugal, 27-30 April 2014; pp. 343-351.

73. Tonelli, F.; Demartini, M.; Loleo, A.; Testa, C. A novel methodology for manufacturing firms value modeling and mapping to improve operational performance in the industry 4.0 era. Procedia CIRP 2016, 57, 122-127. [CrossRef]

74. Barnard, B.; Herbst, D. Innovation and entrepreneurship: The necessary conditions of value creation. Exp. J. Bus. Manag. 2017, 5, 98-128. [CrossRef]

75. Gülyaz, E.; van der Veen, J.A. How logistics \& supply chain can create and appropriate customer value. EVO Logistiek Jaarboek. Available online: https://www.evofenedex.nl/sites/default/files/inline-images/ rb/12ff659fc06ef6cba68b88c0ed54067/How\%20Logistics\%20can\%20Add\%20Customer\%20Value\%20\% 28EVO\%20white\%20paper\%20UK\%29.pdf (accessed on 28 February 2019).

76. Seliger, G. Sustainability Engineering by Product-Service Systems. In Glocalized Solutions for Sustainability in Manufacturing, Proceedings of the 18th CIRP International Conference on Life Cycle Engineering; Springer: Heidelberg, Germany, 2011; pp. 22-28.

77. Jayal, A.D.; Badurdeen, F.; Dillon, O.W.; Jawahir, I.S. Sustainable manufacturing: Modeling and optimization challenges at the product, process and system levels. CIRP J. Manufact. Sci. Technol. 2010, 2, 144-152. [CrossRef]

78. Rogers, E.M. Diffusion of Innovations, 3rd ed.; Collier Macmillan Free Press: New York, NY, USA, 1983.

79. Badurdeen, F.; Shuaib, M.; Liyanage, J.P. Risk modeling and analysis for sustainable asset management. In Engineering Asset Management and Infrastructure Sustainability, Proceedings of the 5th World Congress on Engineering Asset Management (WCEAM), Queensland, Australia, 25-27 October 2011; Springer: London, UK, 2012; pp. 61-75.

80. Boos, W.; Schuh, G. Management of Production Enterprises. In CIRP Encyclopedia of Production Engineering, 1st ed.; Laperrière, L., Reinhart, G., Eds.; Springer: Berlin, Germany, 2014; pp. 821-825.

81. Strandhagen, J.W.; Alfnes, E.; Strandhagen, J.O.; Vallandingham, L.R. The fit of Industry 4.0 applications in manufacturing logistics: A multiple case study. Adv. Manuf. 2017, 5, 344-358. [CrossRef]

82. Roblek, V.; Meško, M.; Krapež, A. A complex view of industry 4.0. SAGE Open 2016, 6, 1-11. [CrossRef]

83. Porter, M.E.; Heppelmann, J.E. How Smart, Connected Products Are Transforming Competition. Harvard Business Review. 2014. Available online: https://hbr.org/2014/11/how-smart-connected-products-aretransforming-competition (accessed on 15 November 2014).

84. Burmeister, C.; Luettgens, D.; Piller, F.T. Business model innovation for industrie 4.0: Why the Industrial Internet" Mandates a New Perspective on Innovation; SSRN Scholarly Paper No. ID 2571033; Social Science Research Network: Rochester, NY, USA, 2015.

85. Rudtsch, V.; Gausemeier, J.; Gesing, J.; Mittag, T.; Peter, S. Pattern-based business model development for cyber-physical production systems. Procedia CIRP 2014, 25, 313-319. [CrossRef]

86. Ghobakhloo, M. The future of manufacturing industry: A strategic roadmap toward Industry 4.0. J. Manufact. Technol. Manag. 2018, 29, 910-936. [CrossRef]

87. Ivanov, D.; Dolgui, A.; Sokolov, B. A dynamic approach to multi-stage job shop scheduling in an industry 4.0-based flexible assembly system. In Advances in Production Management Systems. The Path to Intelligent, Collaborative and Sustainable Manufacturing; Lödding, H., Riedel, R., Thoben, K.D., von Cieminski, G., Kiritsis, D., Eds.; IFIP Advances in Information and Communication Technology; Springer: Cham, Switzerland, 2017.

88. Wildevuur, S.; van Dijk, D.; Hammer-Jacobsen, T.; Bjerre, M.; Äyväri, A.; Lund, J. Connect. In Design for an Empathic Society; BIS Publishers: Amsterdam, The Netherlands, 2013.

89. Woratschek, H.; Schafmeister, G. New business models for the value analysis of sport organisations. In Working Papers in Business Administration and Economics; Working Paper 07-10; Faculty of Law, Business Administration and Economics, Universität Bayreuth: Bayreuth, Germany, 2005. 
90. Schröder, C. The Challenges of Industry 4.0 for Small and Medium-Sized Enterprises; Friedrich-Ebert-Stiftung: Bonn, Germany, 2017.

91. Kiangala, K.S.; Wang, Z. Initiating predictive maintenance for a conveyor motor in a bottling plant using industry 4.0 concepts. Int. J. Adv. Manufact. Technol. 2018, 97, 3251-3271. [CrossRef]

92. Issa, A.; Hatiboglu, B.; Bildstein, A.; Bauernhans, T. Industrie 4.0 roadmap: Framework for digital transformation based on the concepts of capability maturity and alignment. Procedia CIRP 2018, 72, 973-978. [CrossRef]

93. Min, Y.K.; Lee, S.G.; Aoshima, Y. A comparative study on industrial spillover effects among Korea, China, the USA, Germany and Japan. Ind. Manag. Data Syst. 2019, 119, 454-472. [CrossRef]

94. Müller, J.M.; Voigt, K.I. Sustainable industrial value creation in SMEs: A comparison between industry 4.0 and made in China 2025. Int. J. Precis. Eng. Manufact. Green Technol. 2018, 5, 659-670.

(C) 2019 by the authors. Licensee MDPI, Basel, Switzerland. This article is an open access article distributed under the terms and conditions of the Creative Commons Attribution (CC BY) license (http://creativecommons.org/licenses/by/4.0/). 